\title{
Anti-Phospholipase $A_{2}$ Receptor Autoantibody: A New Biomarker for Primary Membranous Nephropathy
}

Quansheng Zhu*

Department of Medicine, David Geffen School of Medicine, UCLA, Los Angeles, California 90095-1689, USA

\begin{abstract}
Primary membranous nephropathy (also known as idiopathic membranous nephropathy, IMN) is an organ specific autoimmune kidney disease characterized by the development of immune complex deposits in the sub-epithelial spaces, podocyte effacement and glomerular capillary wall thickening in the later stages. Clinical studies have demonstrated that over $70 \%$ of patients with IMN possess circulating autoimmune antibodies specifically targeting the phospholipase $\mathrm{A}_{2}$ receptor $\left(\mathrm{PLA}_{2} \mathrm{R}\right)$ on the surface of podocytes. The autoantibodies only bind to the extracellular portion of $\mathrm{PLA}_{2} \mathrm{R}$ under the non-reducing condition, indicating that the epitope in $\mathrm{PLA}_{2} \mathrm{R}$ is conformational requiring specific disulfide bonds to maintain its structure. We recently have successfully located the dominant epitope in $\mathrm{PLA}_{2} \mathrm{R}$ to the extreme N-terminus of the receptor. This finding has opened a new direction for understanding the pathogenesis of anti-PLA $\mathrm{R}_{2} \mathrm{R}$ autoantibody induced IMN and offered a strong basis for developing sensitive clinical assays for IMN diagnosis and prognosis, and potentially, new therapeutic approaches for IMN treatment.
\end{abstract}

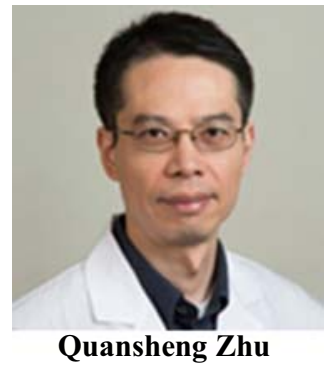

Keywords: Apheresis column, enzyme-linked immunosorbent assay (ELISA), epitope, idiopathic membranous nephropathy (IMN), immunotolerance therapy, integrin $\alpha 3 \beta 1$, kidney, mechanism, pathogenesis, phospholipase $\mathrm{A}_{2}$ receptor $\left(\mathrm{PLA}_{2} \mathrm{R}\right)$.

\section{INTRODUCTION}

Membranous nephropathy $(\mathrm{MN})$ is a common cause of nephrotic syndrome, accounting for $\sim 20$ $40 \%$ of clinical cases in adults over the age of 40 [1-7]. It can be a primary form without identified causes (also known as "idiopathic MN", IMN), or a secondary form associated with various autoimmune diseases, infections, cancers and exposure to drugs or toxic agents $[1,7]$. IMN is an organ specific autoimmune disease. The major antigen responsible for the autoantibody binding in IMN patients was identified to be the phospholipase $\mathrm{A}_{2}$ receptor $\left(\mathrm{PLA}_{2} \mathrm{R}\right)[8]$, an integral transmembrane receptor that binds and removes the secreted phospholipase $\mathrm{A}_{2}$ enzyme ( $\mathrm{SPA}_{2}$ ) from circulation. Clinical studies have demonstrated that over $70 \%$

*Address correspondence to this author at the Department of Medicine, University of California, Los Angeles, 7-155 Factor Building, 10833 Le Conte Ave., Los Angeles, California, 90095-1689, USA; Tel: (310) 206-6741; Fax: (310) 8256309; E-mail: quzhu@mednet.ucla.edu of IMN patients possess circulating autoantibodies that specifically target the PLA $\mathrm{A}_{2} \mathrm{R}$ expressed on the surface of human podocytes [8] and moreover, the level of autoantibodies in circulation correlates with the severity of proteinuria in patients [9-11]. We recently successfully identified the location of the dominant epitope in $\mathrm{PLA}_{2} \mathrm{R}$ in IMN [12]. This finding has opened a new direction for understanding the pathogenesis of anti-PLA ${ }_{2} \mathrm{R}$ autoantibody induced IMN and offered a strong basis for developing sensitive clinical assays for IMN diagnosis and prognosis, and potentially, new therapeutic approaches for IMN treatment.

\section{Pathophysiology of IMN}

IMN is an autoimmune kidney disease that accounts for $\sim 80 \%$ of all $\mathrm{MN}$ cases in adults $[1,13]$. It affects 10-12 people per million population. Clinically, about a third of IMN patients undergo spontaneous remission and about $40 \%$ progress to the end-stage renal disease in $\sim 10-15$ years [1416]. The common clinical manifestation of IMN is 
edema and proteinuria. Pathologically, IMN is characterized by the development of immune complex deposits in the subepithelial spaces causing a membrane-like thickening of the capillary wall and eventually the glomerular basement membrane (GBM). The name of membranous nephropathy derives from the prominent thickened capillary wall that is visible under light microscope in the later stages of the disease. Currently, the diagnosis of IMN is strictly dependent on immunofluorescence and electron microscopy of the renal biopsies, which detects antibody deposition in the peripheral capillary loop, electron dense deposits in the subepithelial spaces and podocyte foot process effacement, respectively. However, such pathology cannot distinguish between the primary and the secondary forms of $\mathrm{MN}$ easily.

The immune deposits in the capillary wall in $\mathrm{MN}$ consist of $\mathrm{IgG}$, antigens, and complement components including the membrane attack complex (complement components C5b-9) [17]. IgG4 is usually the dominant IgG subclass in the immune deposits in IMN, although variable amounts of IgG1, IgG2 and IgG3 are also detected. In contrast, IgG1, IgG2 and IgG3 are usually the dominant depositions in the secondary membranous nephropathy [18-21]. The formation of subepithelial immune deposits and complement activation is believed to be the cause of glomerular capillary wall impairment that leads to proteinuria in patients.

Three mechanisms have been proposed for immune complexes formation and deposition in the lesion of MN [4, 22]: 1) immune complexes are formed in circulation and then deposited in the glomerular subepithelial spaces; 2) immune complexes are formed directly in situ with local antigens; and 3) immune complexes are formed locally with antigens that are planted in the glomerular subepithelial spaces. These mechanisms have been successfully demonstrated in the animal models such as rabbit chronic serum sickness [23, 24], Heymann nephritis [25] and cationic bovine serum albumin induced rabbit $\mathrm{MN}$ [26]. In humans, MN cases with all three of these mechanisms have been demonstrated.

The current understanding of IMN pathogenesis largely derives from an experimental rat model of MN, the Heymann nephritis. In this model, antibodies directly bind to megalin $[27,28]$, a mem- brane receptor located on the basal surface of the rat podocytes that forms immune deposits in situ, which activates the complement pathway that damages podocyte biology leading to proteinuria $[17,29,30]$. Complement activation and C5b-9 membrane attack complex formation play a key role in causing sublethal podocyte injury and proteinuria in the Heymann nephritis. The sublytic level of C5b-9 complex activates various mediators including phospholipases, protein kinases, cyclooxygenases, transcription factors and cytokines that alter podocyte biology over a period of time. The signals generated by these pathways interfere with podocyte metabolism, structure and function of cytoskeletal proteins, expression and localization of nephrin, turnover of extracellular matrix, and DNA integrity. The assembly of the sublytic C5b-9 complex on podocytes was also shown to up-regulate NADPH oxidoreductase expression and translocation to the cell surfaces. Subsequently, reactive oxygen species are produced and accumulate locally, which leads to oxidation of podocyte membrane lipids, membrane proteins and glomerular basement membrane components $[4,13,17,29-31]$.

Although megalin was identified to be the local podocyte antigen in Heymann nephritis, it is not found in the human podocytes $[6,32]$. Two membrane proteins, the neutral endopeptidase (NEP) [33] and $\mathrm{PLA}_{2} \mathrm{R}$ [8] expressed on the basal surface of podocytes have been identified to serve as the local antigens for the neonatal alloimmune and adult IMN respectively. More recently, a new antigen, thrombospondin type-1 domain-containing $7 \mathrm{~A}$ was also identified to serve as a local antigen in $\sim 2.5-5 \%$ of adult patients with IMN [34].

\section{Anti-PLA2 R Autoantibody and IMN}

In 2009, Beck and coworkers made a seminal discovery that, about $70 \%$ of patients in the United States with IMN, but not in those with secondary $\mathrm{MN}$ or in controls, possess anti-PLA $\mathrm{A}_{2} \mathrm{R}$ autoantibodies in circulation that specifically bind to the $\mathrm{PLA}_{2} \mathrm{R}$ expressed in podocytes [8]. The autoantibodies were found to be deposited within the subepithelial immune complexes in patients with IMN, and the eluted autoantibodies from biopsy specimen reacted with $\mathrm{PLA}_{2} \mathrm{R}$ on the Westernblot. The antigen, $\mathrm{PLA}_{2} \mathrm{R}$ was also found in the immune complex deposits at a very high level. Importantly, the autoantibody only recognized the 
non-reduced form of $\mathrm{PLA}_{2} \mathrm{R}$, indicating that the epitope in $\mathrm{PLA}_{2} \mathrm{R}$ is conformational requiring specific disulfide bonds to maintain its structure.

Since this initial discovery, multiple cohort studies have been performed across the world to determine the prevalence of anti-PLA ${ }_{2} \mathrm{R}$ autoantibodies in IMN patients [9-11, 35-44]. Four techniques have been used to detect the presence of autoantibodies in patients: Western-blotting of $\mathrm{PLA}_{2} \mathrm{R}$ protein under the nonreducing condition (WB), recombinant cell-based indirect immunofluorescence assay (IFA), enzyme-linked immunosorbent assay (ELISA) and immunofluorescence staining of renal biopsies. The available results indicated that the prevalence of anti-PLA ${ }_{2} \mathrm{R}$ autoantibodies in IMN patients varies significantly in different regions. Specifically, cohort studies showed that the prevalence of anti-PLA 2 R autoantibodies in IMN patients in China [36], Korea [37], Japan [38], Iran [39], Germany [40], UK [9] and Netherlands [41] is $81.7 \%, 69 \%, 53 \%, 75 \%, 69 \%$, $75 \%$ and $74 \%$ respectively. Of all the cohort studies, 5 had a sample size over 100 cases, and the average prevalence of anti-PLA $\mathrm{A}_{2} \mathrm{R}$ autoantibodies across the world in IMN patients is about $70 \%$. Results from 3 European studies indicated that the level of autoantibodies in circulation correlates with the severity of proteinuria and the clinical outcomes in patients [9-11]; yet results from 2 Asian studies indicated that no significant correlations could be detected [37, 38]. This discrepancy may be caused by different techniques used in the cohort studies. Occasionally, the anti-PLA ${ }_{2} \mathrm{R}$ antibody was detected in the secondary $\mathrm{MN}$ (cancer and hepatitis B) [36] but it is unknown if this is merely a chance occurrence.

The pathogenic role of anti-PLA ${ }_{2} \mathrm{R}$ autoantibody in IMN was also studied in the kidney transplant recipients. It was reported that IMN could recur one week after kidney transplantation when circulating anti-PLA ${ }_{2} \mathrm{R}$ antibodies were present at the time of transplantation $[45,46]$. It was also reported that some patients with high titers of autoantibodies at the time of kidney transplantation did not have recurrence [45]. Moreover, the recurrence of anti-PLA $A_{2} R$ autoantibody in IMN patients after kidney transplant [47, 48] was found to be associated strongly with the disease relapse, supporting that the autoantibody serves as the cause of IMN in patients.
Unlike the anti-NEP autoantibody in neonatal alloimmune $\mathrm{MN}$ [33], transfer of anti-PLA ${ }_{2} \mathrm{R}$ patient sera to animals failed to reproduce nephrotic syndrome as that in human. This is likely due to the fact that $\mathrm{PLA}_{2} \mathrm{R}$ is not expressed in the glomerulus of rabbit, rat or mouse [8]. A recent study successfully generated a $\mathrm{PLA}_{2} \mathrm{R}$ knock-in mouse model with human $\mathrm{PLA}_{2} \mathrm{R}$ specifically expressed in the mouse podocytes [49]. Transfusion of human anti-PLA $A_{2} R$ sera into the $P_{2} A_{2} R$ knock-in mice indeed triggered immune complex deposition in the glomerular subepithelial spaces; however, no proteinuria was detected in these animals. This unexpected finding seems to indicate that formation of the immune deposit itself is not sufficient enough to cause proteinuria in patients, and that complement activation or additional mechanisms must be involved, as shown in the Heymann nephritis.

In Heymann nephritis, immune deposits formation and complement activation, as well as a $\mathrm{T}$ cell (CD8) involvement are critically required for developing proteinuria in the animals. Depletion of complement components obviated proteinuria in the animal models despite the presence of $\mathrm{IgG}$ containing immune deposits in the GBM [50]. The dominant anti-PLA ${ }_{2} \mathrm{R}$ autoantibody detected in the renal biopsies of IMN patients is IgG4 (other subclasses are also detected at relatively low levels). IgG4 is known to be ineffective to activate the classical complement pathway, suggesting that the mechanism of anti-PLA $\mathrm{A}_{2} \mathrm{R}$ autoantibody induced proteinuria in patients may differ significantly from that in the Heymann nephritis. A recent study suggested that aberrant glycosylated IgG4 may play an important role in activating complements via the mannose-binding lectin (MBL) pathway [51], and indeed, MBL components can be found in the immune complex deposits of IMN [52]. In a special clinical case where a patient had recurrent IMN after kidney transplantation, the anti-PLA ${ }_{2} \mathrm{R}$ autoantibody was identified to be IgG3k, which is capable of activating the classical complement pathway directly [53].

Similar to the type I autoimmune pancreatitis [54], human IMN is an IgG4-related disease with the glomerular immune deposits containing predominantly IgG4-subclass antibodies, indicating the involvement of T helper 2 cells (CD4) in immune response $[55,56]$. Clinical studies indeed showed that in IMN patients, the $\mathrm{CD}^{+} / \mathrm{CD} 8^{+}$ratio 
of peripheral T cells and the level of IL-10 and IL13 mRNA expression in peripheral blood mononuclear cells significantly increased [56]. It is likely that in IMN patients, the antigen primed $\mathrm{T}$ helper 2 cells engaged with specific B cells secret IL-10 and IL-13 that activates B cells and promotes IgG4 autoantibody production.

\section{Structure and Function of $\mathrm{PLA} \mathrm{A}_{2} \mathrm{R}$}

\section{Molecular Structure}

Two forms of PLA ${ }_{2} \mathrm{R}$ exist in the body: a membrane associated form $\left(\mathrm{PLA}_{2} \mathrm{R}\right)$ and a circulative form $\left(\mathrm{cPLA}_{2} \mathrm{R}\right)[57,58]$. The membrane associated $\mathrm{PLA}_{2} \mathrm{R}$ is a type I transmembrane glycoprotein (MW $\sim 180 \mathrm{kDa}$ ) consisting of a large glycosylated extracellular portion, a single transmembrane helix and a short cytoplasmic tail. The circulating $\mathrm{PLA}_{2} \mathrm{R}$ is a truncated form of the membrane associated $\mathrm{PLA}_{2} \mathrm{R}$ that only contains the extracellular portion due to alternative splicing [57]. In the kidney, both forms of $\mathrm{PLA}_{2} \mathrm{R}$ are present with a ratio of 1.6:1 ( $\left.\mathrm{PLA}_{2} \mathrm{R}: \mathrm{cPLA}_{2} \mathrm{R}\right)$ at the mRNA level [57]. Surprisingly, the anti-PLA $A_{2} R$ autoantibody only recognizes and binds to the membrane associated but not the circulative $\mathrm{PLA}_{2} \mathrm{R}$ [8], suggesting that the two forms of $\mathrm{PLA}_{2} \mathrm{R}$ may fold differently. The current review focuses on the structure and function of the membrane associated PLA $\mathrm{A}_{2} \mathrm{R}$.

$\mathrm{PLA}_{2} \mathrm{R}$ belongs to the mannose receptor family that consists of four members: the mannose receptor (CD206), Endo180 (also known as the urokinase type plasminogen activator receptorassociated protein uPARAP or CD280), the dendritic cell receptor DEC205 (CD205) and PLA 2 R $[59,60]$. All the 4 receptors share a similar threedimensional protein structure, especially in the extracellular portion, which contains an N-terminal cysteine-rich domain (CysR) followed by a single fibronectin-like type II domain (FnII), and eight to ten C-type lectin-like domains (CTLD), Fig. (1). The protein structure of the individual CysR, FnII and CTLD domain has been solved at the atomic level which showed the critical roles of disulfide bonding in the proper folding of each of the domains [61-63]. Single particle electron microscopy images of the extracellular portion of mannose receptor and Endo180 are also available [64], which indicated that both molecules have two distinctive configurations: a bent conformation with the Nterminal domains folding back toward the middle

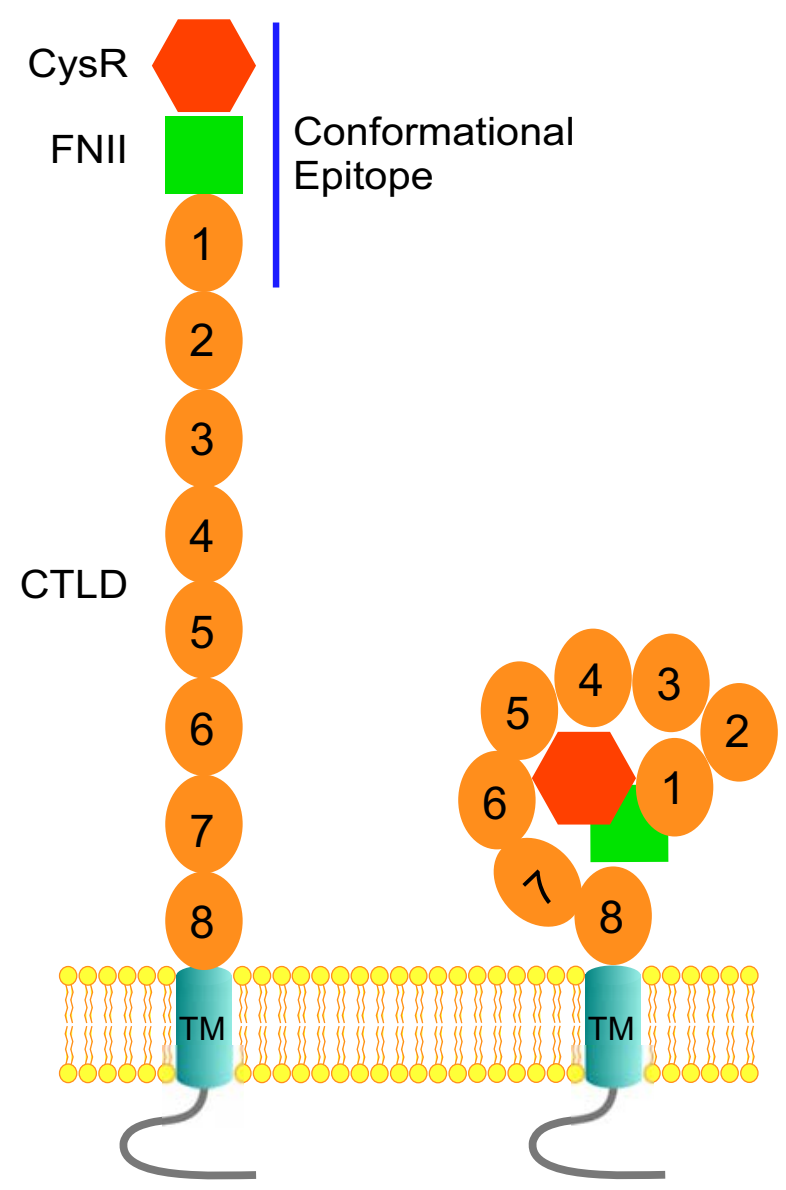

Fig. (1). The extended (left) and the bent (right) configurations of $\mathrm{PLA}_{2} \mathrm{R}$ in the cell membranes. The immunodominant epitope region for autoantibody recognition is indicated as a solid line.

of the molecule, and an extended conformation with the N-terminal CysR domain pointing outwards from the cell membrane [59]. Transitions between the "bent" and "extended" conformation have been predicted to serve as a general structural mechanism for the mannose receptor family to regulate their ligands binding.

As a member of the mannose receptor family, the extracellular portion of $\mathrm{PLA}_{2} \mathrm{R}$ has also been predicted to have a bent and an extended conformation on the cell surfaces [8] Fig. (1). Whether each of the domains in $\mathrm{PLA}_{2} \mathrm{R}$ is arranged in a similar configuration to that of the mannose receptor in three-dimensional structure is not clear. The difference in autoantibody recognition between the circulating and the membrane associated $\mathrm{PLA}_{2} \mathrm{R}$ seems to indicate that a conformational mechanism is involved in exposing the epitope in $\mathrm{PLA}_{2} \mathrm{R}$ for the autoantibody binding. 


\section{Biological Function}

Of all the mannose receptor family members, the mannose receptor is known to be involved in the pathogen recognition in the innate immune system; DEC-205 involved in antigen presentation in the dendritic cells; Endo 180/uPARAP involved in regulating extracellular matrix degradation and remodeling. However, the biological function of $\mathrm{PLA}_{2} \mathrm{R}$ has remained largely unclear. $\mathrm{PLA}_{2} \mathrm{R}$ was identified two decades ago based on its high affinity for the venom secreted phospholipase $A_{2}$ [65]. Following its cloning, the affinity of $\mathrm{PLA}_{2} \mathrm{R}$ for different $\mathrm{sPLA}_{2}$ family members was analyzed, and a pancreatic form of $\mathrm{sPLA}_{2}\left(\mathrm{sPLA}_{2}-\mathrm{IB}\right)$ was shown to have the highest affinity [58]. Binding of $\mathrm{sPLA}_{2}$ to $\mathrm{PLA}_{2} \mathrm{R}$ triggers rapid receptor endocytosis, indicating that $\mathrm{PLA}_{2} \mathrm{R}$ functions as a scavenger receptor for removal of the bound $\mathrm{SPLA}_{2}$ from circulation [66]. Binding of $\mathrm{sPLA}_{2}$ to $\mathrm{PLA}_{2} \mathrm{R}$ was also found to activate signaling pathways that triggers cellular responses [67, 68]. Indeed, studies from cultured cells as well as experimental animal models both supported the contention that $\mathrm{PLA}_{2} \mathrm{R}$ is a signaling receptor in cell membranes. Recent reports also suggested that $\mathrm{PLA}_{2} \mathrm{R}$ plays an important role in cell senescence [69] and tumor suppression [70], further supporting the concept that $\mathrm{PLA}_{2} \mathrm{R}$ functions as a signaling molecule in the cell membranes.

$\mathrm{PLA}_{2} \mathrm{R}$ has also been reported to function as an endogenous inhibitor for $\mathrm{SPLA}_{2}$ in the lung with elevated expression levels during lung infection [71], suggesting its important role in inflammation. However, the biological role of $\mathrm{PLA}_{2} \mathrm{R}$ in the kidney has remained completely unknown despite it being highly expressed in the basal membrane of podocytes [8]. $\mathrm{PLA}_{2} \mathrm{R}$ was predicted to have a protective role for podocyte plasma membranes against being attacked by $\mathrm{SPLA}_{2}$ enzymes. Intriguingly, in vitro biochemical assays showed that although $\mathrm{SPLA}_{2}$-IB actively digests phospholipids when mixed with bile, it has minimal activity in digesting membrane phospholipids [72]. sPLA $\mathrm{S}_{2}$-IB has a molecular weight of $14 \mathrm{kDa}$ and is readily filtered, so it is unlikely to cause damage to the podocyte plasma membranes. Surprisingly, when the $\mathrm{PLA}_{2} \mathrm{R}$ gene was knocked out, mice appeared completely normal with no disease phenotype [73]. These observations seem to suggest that $\mathrm{PLA}_{2} \mathrm{R}$ has a minimal role in podocyte function; however, clinical evidence clearly demonstrated its involvement in mediating podocyte injury in IMN when bound with the anti-PLA ${ }_{2} \mathrm{R}$ autoantibodies, suggesting that additional physiological roles other than being a functional inhibitor for ${ } P_{L} A_{2}$ in human kidney might be involved.

\section{Tissue Distribution}

After its cloning, the distribution of $\mathrm{PLA}_{2} \mathrm{R}$ in human tissue was analyzed by RNA blotting, which showed that $P_{L A} R$ is highly expressed in the pancreas [74], kidney [57, 74], placenta [57, 74], lung [57] and skeletal muscle [57]. Interestingly, $\mathrm{PLA}_{2} \mathrm{R}$ mRNA was only detected in the kidney at a very high level in the human fetus [74]. Lately, $\mathrm{PLA}_{2} \mathrm{R}$ expression was also detected in the human neutrophils [75], gestational tissues [76], the primary human mammary epithelial cells [69], human diploid cells [69] and leukemic cells [77]. Based on the mRNA expression pattern of PLA ${ }_{2} \mathrm{R}$ in GeneAtlas (provided by Genomics Institute of the Novartis Research Foundation), $\mathrm{PLA}_{2} \mathrm{R}$ is widely expressed throughout the body.

\section{Epitope in $\mathrm{PLA}_{2} \mathrm{R}$ for Autoantibody Binding in IMN}

The anti-PLA $A_{2} \mathrm{R}$ autoantibody specifically binds to the extracellular portion of $\mathrm{PLA}_{2} \mathrm{R}$ under the nonreducing condition [8], indicating that the epitope is conformational and requires specific disulfide bonds to maintain its structure. A disulfide bond is formed by sulfhydryl groups of two adjacently located cysteine amino acids in a folded protein. $\mathrm{PLA}_{2} \mathrm{R}$ contains 66 endogenous cysteines throughout the extracellular portion, and disulfide bonds are likely to be present in every one of the 10 domains. The conformational epitope in $\mathrm{PLA}_{2} \mathrm{R}$ could be formed either by a single or by multiple extracellular domains in a folded conformation. Genetic studies have determined that several polymorphisms exist in the extracellular portion of $\mathrm{PLA}_{2} \mathrm{R}$ in IMN patients, especially, M292V and H300D in the CTLD1 domain and G1106S in the linker region between CTLD6 and CTLD7 domain may correlate with the occurrence of IMN in patients with susceptible genetic backgrounds [78, 79]. By using small peptide mapping approach, a number of regions in the $\mathrm{PLA}_{2} \mathrm{R}$ extracellular portion have been predicted to bind to the autoantibodies, suggesting that the epitope in $\mathrm{PLA}_{2} \mathrm{R}$ could potentially be distributed throughout the extracellular portion [80]. 


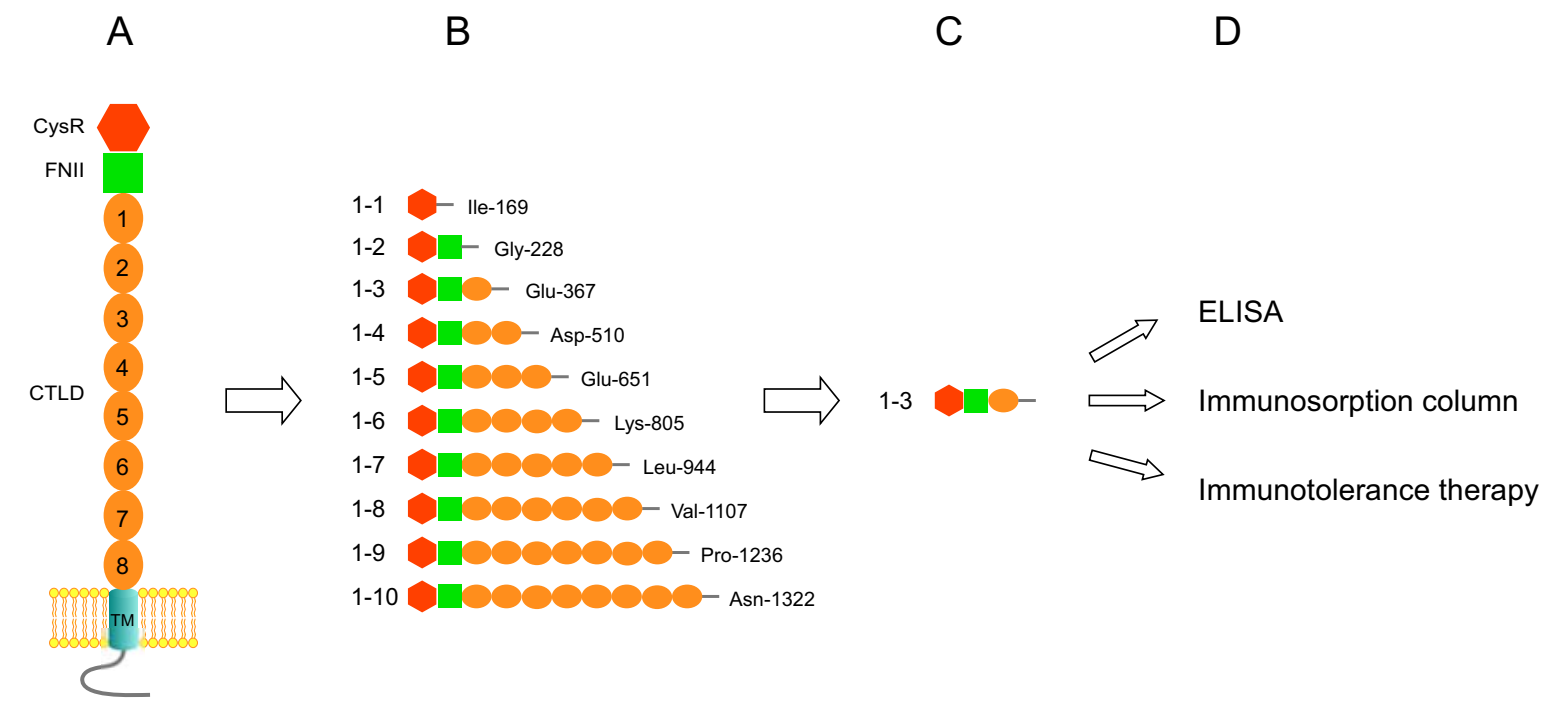

Fig. (2). Identification of the dominant epitope in $P_{L A} R$ in IMN and its clinical applications. A. Topological model of PLA $A_{2} R$ in the cell membranes. B. Truncated $\mathrm{PLA}_{2} \mathrm{R}$ extracellular domains for IMN patient sera probing on the Western-blot. C. The identified dominant epitope region. D. Clinical applications of the identified epitope in $P_{L A} R$.

Since $\mathrm{PLA}_{2} \mathrm{R}$ is widely expressed yet IMN is an organ specific disease, we predicted that the $\mathrm{PLA}_{2} \mathrm{R}$ expressed in human podocytes adopt a unique conformation with a specific epitope region highly exposed for the autoantibody binding. To test this hypothesis, we sequentially truncated the extracellular portion of $\mathrm{PLA}_{2} \mathrm{R}$ into 10 protein fragments that contain CysR, CysR and FnII, CysR, FnII and CTLD1-10 domains, Fig. (2). These protein fragments were selectively truncated in the linker regions between each of the domains, to minimize the potential structural disturbance. By probing the truncated $\mathrm{PLA}_{2} \mathrm{R}$ domains expressed in the HEK 293 cells, we successfully determined that the dominant epitope for autoantibody binding is exclusively located in the extreme $\mathrm{N}$-terminus of the receptor, specifically, a region encompassing the CysR-FnII-CTLD1 domain [12]. This epitope was recognized strongly by the sera from various patients that contained anti$\mathrm{PLA}_{2} \mathrm{R}$ autoantibodies, but not by the sera that were negative of the autoantibodies. Importantly, the isolated epitope region completely blocked the autoantibody binding to the full length $\mathrm{PLA}_{2} \mathrm{R}$ protein on the Western-blot, indicating that the epitope in its native conformation binds strongly to the autoantibody. Our data also demonstrated that all the three domains are required to form an integrated structure for the autoantibody recognition, and neither of the individual domains alone could serve as the epitope on the Western-blot. Therefore, we propose that the epitope in $\mathrm{PLA}_{2} \mathrm{R}$ is formed by regions from the CysR and the CTLD1 domain with FnII domain serves as a critical structural component to bring the two domains in a close proximity. Indeed, the EM structures of both mannoses receptor and Endo180 showed that the CysR-FnII-CTLD1 domains are compactly folded, indicating that regions in the CysR and CTLD1 domains are close enough to form a conformational epitope $[64,81]$.

Shortly after our discovery, a similar study on identifying the epitope in $\mathrm{PLA}_{2} \mathrm{R}$ in IMN patients was reported [82]. This study initially determined that the epitope was exclusively located in the CTLD3 domain based on the results using smallangle X-ray scattering, electron microscopy and surface plasmon resonance approaches [83], and in the final published manuscript [82], the epitope was relocated to the CysR domain that corroborated our finding. Specifically, the study determined that a 31 amino acid peptide in the CysR domain forms a major epitope that is recognized by the anti-PLA $A_{2} \mathrm{R}$ autoantibodies. Moreover, the study determined that this epitope could only be maintained under the non-denaturing condition, and that the CTLD3 domain is essentially required for keeping the epitope conformation under the denaturing condition. In our study, the region encompassing the CysR-FnII-CTLD1 domain was well recognized by the autoantibodies from various patients on the Western-blot under the denaturing condition. This discrepancy requires further investigation. Nevertheless, this study clearly sup- 
ported our conclusion that the dominant epitope in $\mathrm{PLA}_{2} \mathrm{R}$ in IMN is located at the extreme $\mathrm{N}$ terminus of the receptor.

\section{Pathophysiological and Clinical Significance of Epitope Identification}

\section{Pathophysiological Significance}

IMN is an organ specific autoimmune disease. The endogenous antigen, $\mathrm{PLA}_{2} \mathrm{R}$, is not only expressed in the human kidney, but also highly expressed in the lung, pancreas, placenta, neutrophils, cardiomyocytes and many other tissues. Why the autoantibodies only target the $\mathrm{PLA}_{2} \mathrm{R}$ expressed on the surface of podocytes in the kidney, but not in other organs, has remained completely unclear. Based on the NMR structure of the mannose receptor, $\mathrm{PLA}_{2} \mathrm{R}$ is likely to have an extended and a bent conformation on the cell surface, and the autoantibodies were thought to bind only one of the conformations. Therefore, IMN was predicted to be an autoimmune conformational disease, termed as "conformerapathy" [84], which means the antigen is formed due to a specific conformation of the receptor.

Our finding that the dominant epitope in $\mathrm{PLA}_{2} \mathrm{R}$ is exclusively located at the extreme $\mathrm{N}$ terminus has offered a new level of understanding of the disease pathogenesis and potentially a plausible explanation why IMN is an organ specific autoimmune disease. We predict that the $\mathrm{PLA}_{2} \mathrm{R}$ expressed on the basal surface of the podocytes adopts an extended conformation towards the GBM facing the incoming plasma fluid and as a result is highly accessible to autoantibody binding; yet in other organs, $\mathrm{PLA}_{2} \mathrm{R}$ adopts a bent conformation that precludes the epitope region being recognized by the autoantibodies. In supporting of this hypothesis, we have determined that the extracellular domains of $\mathrm{PLA}_{2} \mathrm{R}$ associate with integrin $\alpha 3 \beta 1[3,85]$, an adhesion molecule in the podocytes. Integrin $\alpha 3 \beta 1$ is highly expressed in the basal surface of the podocytes, where it mediates podocytes attachment to the GBM. Integrin molecule is known to have a bent conformation in the inactive state, and become extended in the active state when interacting with its ligand [86]. Association of $\mathrm{PLA}_{2} \mathrm{R}$ extracellular domains with the active form integrin $\alpha 3 \beta 1$ is likely to induce the receptor to adopt an extended conformational that highly exposes the $\mathrm{N}$-terminal dominant epitope for autoantibody binding.

Although the anti-PLA ${ }_{2} \mathrm{R}$ autoantibody is now considered to be the cause of IMN in patients, how the autoantibody is produced initially in the body has remained unclear. In human glomeruli, $\mathrm{PLA}_{2} \mathrm{R}$ is only expressed in the podocytes [8], and podocytes are epithelial cells separated from circulation by the GBM. Therefore, it is unlikely that exposure of the dominant epitopes in $\mathrm{PLA}_{2} \mathrm{R}$ on the surface of podocytes can serve as the trigger for the autoantibody production since they are inaccessible to the circulating $\mathrm{T}$ cells, which help to activate the antigen specific $B$ cells and promote antibody formation and secretion. Identification of the dominant epitope in $\mathrm{PLA}_{2} \mathrm{R}$ has offered an important clue in searching for unknown environmental agents that are potentially to serve as the trigger for the autoantibody production in the body, and subsequently the produced antibodies cross-reacting with the $\mathrm{PLA}_{2} \mathrm{R}$ epitope on the surface of human podocytes through molecular mimicry mechanism.

Comparison of the 31 amino acids in CysR domain against the microbial protein database revealed that a bacterial cell wall enzyme, D-alanylD alanine carboxypeptidase, shares a sequence of "LTLENCK" completely with the CysR domain [82], suggesting its potential role to serve as an environmental trigger for IMN. Our study indicated that the CTLD1 domain is critically required for forming the conformational epitope [12], and therefore we compared the amino acid sequence of CTLD1 domain against the NCBI database of nonredundant protein sequences. We found surprisingly that a bacterial subgroup of the C-type lectin-like domain and an invertebrate C-type lectin, CEL-I in the secreted toxin of two ocean organisms Table 1 are about 20-25\% homologous to CTLD1. We postulate that exposure to these environmental agents might induce the production of pathogenic anti-PLA $\mathrm{A}_{2} \mathrm{R}$ autoantibodies in a genetically susceptible population.

\section{Clinical Significance}

Currently, clinical diagnosis of $\mathrm{MN}$ is strictly dependent on renal biopsies that requires signify 
Table 1. Human PLA 2 R CTLD-1 domain homologous protein in a group of bacterial and two ocean organisms.

\begin{tabular}{|c|c|c|c|}
\hline \multicolumn{4}{|c|}{ Human PLA 2 R CTLD-1 homologous domain in a subgroup of bacterial C-type lectin-like domain proteins } \\
\hline Gene ID & Definition & Source organism & Alignment score \\
\hline gi 78171192 & C-type lectin & Chlorobium chlorochromatii CaD3 & 21.58 \\
\hline gi 33863107 & $\begin{array}{l}\text { C-type lectin domain-containing } \\
\text { protein }\end{array}$ & $\begin{array}{c}\text { Prochlorococcus marinus str. MIT } \\
9313\end{array}$ & 15.83 \\
\hline gi 86135736 & $\begin{array}{l}\text { Hypothetical protein } \\
\text { MED193_16474 }\end{array}$ & Roseobacter sp. MED193 & 15.11 \\
\hline gi 87308660 & $\begin{array}{l}\text { Hypothetical protein } \\
\text { WH7805_05191 }\end{array}$ & Synechococcus sp. WH 7805 & $10.79 / 17.99$ \\
\hline gi 32471540 & Hypothetical protein RB1661 & Rhodopirellula baltica $\mathrm{SH} 1$ & 12.23 \\
\hline gi 32472568 & $\begin{array}{l}\text { Heme/hemopexin utilization protein } \\
\text { huxA }\end{array}$ & Rhodopirellula baltica $\mathrm{SH} 1$ & 12.23 \\
\hline gi 57506013 & TraN protein, homolog & $\begin{array}{c}\text { Campylobacter upsaliensis } \\
\text { RM3195 }\end{array}$ & 12.95 \\
\hline gi 59802590 & $\begin{array}{l}\text { Cyclin-dependent kinase-activating } \\
\text { kinase }\end{array}$ & Prosthecobacter dejongeii & 13.67 \\
\hline gi 72003075 & C-type lectin & $\begin{array}{c}\text { Prochlorococcus marinus str. } \\
\text { NATL2A }\end{array}$ & 15.11 \\
\hline gi 78166157 & VCBS protei & Chlorobium luteolum DSM 273 & 15.83 \\
\hline gi 86134618 & VCBS & Tenacibaculum sp. MED152 & 15.83 \\
\hline gi 86749366 & VCBS & Rhodopseudomonas palustris HaA2 & 9.35 \\
\hline gi 87124836 & $\begin{array}{l}\text { Hypothetical protein } \\
\text { RS9917_01402 }\end{array}$ & Synechococcus sp. RS9917 & 10.79 \\
\hline gi 32477673 & $\begin{array}{l}\text { Mannan-binding protein MBP } \\
\text { (lectin) }\end{array}$ & Rhodopirellula baltica SH 1 & 15.83 \\
\hline gi 87310299 & Serine/threonine protein kinase & Blastopirellula marina DSM 3645 & 15.11 \\
\hline gi 67925505 & YD repeat & Crocosphaera watsonii WH 8501 & 19.42 \\
\hline \multicolumn{4}{|c|}{ Human PLA $A_{2}$ CTLD-1 homologous domain in CEL-1 from Cucumaria echinata and Echinoidin from Anthocidaris crassispina } \\
\hline Gene ID & Definition & Source organism & Alignment Score \\
\hline gi 126127 & Echinoidin & Heliocidaris crassispina & 25.18 \\
\hline gi 3378108 & secreted lectin homolog & Heliocidaris erythrogramma & 20.86 \\
\hline gi 17385630 & GalNAc-specific lectin & Asterina pectinifera & 19.42 \\
\hline gi 21637389 & C-type lectin domain protein & Strongylocentrotus purpuratus & 20.14 \\
\hline gi 37732133 & spEchinoidin & Strongylocentrotus purpuratus & 19.42 \\
\hline gi 68357792 & $\begin{array}{l}\text { PREDICTED: similar to } \\
\text { hCG1657150 }\end{array}$ & Danio rerio & 12.23 \\
\hline gi 72010149 & $\begin{array}{l}\text { PREDICTED: similar to secreted } \\
\text { lectin homolog; HeEL-1 }\end{array}$ & Strongylocentrotus purpuratus & 19.42 \\
\hline gi 72015052 & $\begin{array}{l}\text { PREDICTED: aggrecan core pro- } \\
\text { tein-like }\end{array}$ & Strongylocentrotus purpuratus & 25.18 \\
\hline gi 72085529 & PREDICTED: echinoidin-like & Strongylocentrotus purpuratus & 22.3 \\
\hline gi 72125841 & $\begin{array}{l}\text { PREDICTED: aggrecan core pro- } \\
\text { tein-like isoform } 2\end{array}$ & Strongylocentrotus purpuratus & 24.46 \\
\hline gi 73959018 & $\begin{array}{l}\text { PREDICTED: similar to Neurocan } \\
\text { core protein precursor (Chondroitin } \\
\text { sulfate proteoglycan } 3)\end{array}$ & Canis familiaris & 12.96 \\
\hline
\end{tabular}


cant sample processing time, and the method itself potentially poses a risk of kidney bleeding. The discovery of $\mathrm{PLA}_{2} \mathrm{R}$ as the major antigen in IMN has opened new avenues into the diagnosis and treatment of IMN. Serological tests, such as indirect IFA [35] and ELISA [87, 88], are available on the market with sensitivity for anti-PLA ${ }_{2} \mathrm{R}$ autoantibodies around $70 \%$. IFA utilizes formalin fixed $\mathrm{PLA}_{2} \mathrm{R}$ expressing HEK 293 cells coated on a coverslip, and ELISA utilizes purified full extracellular portion of $\mathrm{PLA}_{2} \mathrm{R}$ protein, as the target antigens for detecting the presence of autoantibodies in patient sera. It is known that human sera are a mixture containing variety of antibodies; application of such mixture on the fixed human cells will inevitably produce high background. Indeed, IFA could not be used to monitor the autoantibody titer in patient sera and analysis of IFA results is subjective depending on experiences [89]. Identification of the antigenic epitope in $\mathrm{PLA}_{2} \mathrm{R}$ has now made it possible to develop a sensitive and costeffective epitope specific ELISA assay for detecting the autoantibodies in patient sera. We coated the identified epitope region on an ELISA plate and tested its efficiency for the anti-PLA $A_{2} R$ autoantibody recognition. Our preliminary data showed that the new assay can detect the presence of autoantibodies up to 1:6,400 dilutions, and moreover, has a ratio of $\sim 10-15$ fold of the autoantibody positive vs. negative sera. Our assay has offered a new level of sensitivity and cost effectiveness for detecting the autoantibodies in patient sera, monitoring the disease prognosis, and differentiating the primary and the secondary $\mathrm{MN}$ in patients.

Identification of the dominant epitope in $\mathrm{PLA}_{2} \mathrm{R}$ has also offered a strong basis for developing specific treatments for patients with anti$\mathrm{PLA}_{2} \mathrm{R}$ autoantibody induced IMN. Clinically, IMN patients are treated routinely with high doses of steroids and immunosuppressive agents, which are non-specific and have significant side effects. In some patients, these treatments are not effective. Moreover, the slow decline in circulating autoantibodies after treatment exposes the podocytes to the risk for ongoing injury $[90,91]$. If the autoantibodies can be removed selectively from the patient circulation, it may effectively stop the disease progress in the early stage, which would reverse the abnormalities in kidney function with minimal side-effects [92]. We have successfully built an epitope coated apheresis column and tested its effectiveness for autoantibody removal from the patient sera. Our obtained results have demonstrated that the column has a very high capacity and efficiency to bind and remove the autoantibodies from patient sera, indicating its future potential for IMN treatment. We envision this new treatment will specifically remove the anti$\mathrm{PLA}_{2} \mathrm{R}$ autoantibodies from circulation without affecting the level of normal antibodies and therefore poses no undesirable immunosuppressive side-effects to the patients.

Alternatively, the identified epitope could be used as a reagent for developing immunotolerance therapies $[93,94]$ for IMN patients. Immunotolerance is a state of immune unresponsiveness toward a particular antigen due to repeated antigen exposure that results in peripheral $\mathrm{T}$ cell tolerance. Immune tolerance therapy intends to reprogram the immune system so that it stops producing autoantibodies. We predict that IMN patients could be exposed to the purified epitope region repeatedly over a period of time until the body tolerates the $\mathrm{PLA}_{2} \mathrm{R}$ epitope without reacting to it. This treatment may potentially stop the anti-PLA ${ }_{2} \mathrm{R}$ autoantibody production in IMN patients and have long lasting effects.

\section{CONCLUSION}

For the past half century, the pathogenesis of primary membranous nephropathy has been uncertain, and it was referred to as "idiopathic". With the application of modern technologies in renal disease research, especially protein mass spectrometry, we now have entered into a new era of elucidating the pathogenesis of renal autoimmune diseases. In regard to IMN research, we expect in a near future that a panel of antigens responsible for IMN in patients will be discovered. As a result, we believe that the strict dependence of IMN diagnosis on renal biopsies will one day be fully replaced by the laboratory tests.

\section{CONFLICT OF INTEREST}

The author confirms that this article content has no conflict of interest. 


\section{ACKNOWLEDGEMENTS}

We thank Dr. Richard Glassock for critical reading of the manuscript. This work was supported in part by the Norman S. Coplon Grant from Satellite Healthcare and funding from the UCLA Division of Nephrology.

\section{REFERENCES}

[1] Glassock, R.J. The pathogenesis of idiopathic membranous nephropathy: A 50-year odyssey. Am. J. Kidney Dis., 2010, 56(1), 157-167.

[2] Glassock, R.J. The pathogenesis of membranous nephropathy: Evolution and revolution. Curr. Opin. Nephrol. Hypertens, 2012, 21(3), 235-242.

[3] Glassock, R.J. Pathogenesis of membranous nephropathy: A new paradigm in evolution. Contrib. Nephrol., 2013, 181, 131-142.

[4] Ronco, P.; Debiec, H. Pathogenesis of membranous nephropathy: Recent advances and future challenges. Nat. Rev. Nephrol., 2012, 8(4), 203-213.

[5] Ronco, P.; Debiec, H. Anti-phospholipase A2 receptor antibodies and the pathogenesis of membranous nephropathy. Nephron. Clin. Pract., 2014, 128(3-4), 232-237.

[6] Beck, L.H., Jr.; Salant, D.J. Membranous nephropathy: Recent travels and new roads ahead. Kidney Int., 2010, 77(9), 765-770.

[7] Beck, L.H., Jr.; Salant, D.J. Membranous nephropathy: From models to man. J. Clin. Invest., 2014, 124(6), 2307-2314.

[8] Beck, L.H., Jr.; Bonegio, R.G.; Lambeau, G.; Beck, D.M.; Powell, D.W.; Cummins, T.D.; Klein, J.B.; Salant, D.J. M-type phospholipase A2 receptor as target antigen in idiopathic membranous nephropathy. N. Engl. J. Med., 2009, 361(1), 11-21.

[9] Kanigicherla, D.; Gummadova, J.; McKenzie, E.A.; Roberts, S.A.; Harris, S.; Nikam, M.; Poulton, K.; McWilliam, L.; Short, C.D.; Venning, M.; Brenchley, P.E. Anti-PLA2R antibodies measured by ELISA predict long-term outcome in a prevalent population of patients with idiopathic membranous nephropathy. Kidney Int., 2013, 83(5), 940-948.

[10] Hofstra, J.M.; Beck, L.H., Jr.; Beck, D.M.; Wetzels, J.F.; Salant, D.J. Anti-phospholipase A receptor antibodies correlate with clinical status in idiopathic membranous nephropathy. Clin. J. Am. Soc. Nephrol., 2011, 6(6), 1286-1291.
[11] Hoxha, E.; Thiele, I.; Zahner, G.; Panzer, U.; Harendza, S.; Stahl, R.A. Phospholipase A2 receptor autoantibodies and clinical outcome in patients with primary membranous nephropathy. $J$. Am. Soc. Nephrol., 2014, 25(6), 1357-1366.

[12] Kao, L.; Lam, V.; Waldman, M.; Glassock, R.J.; Zhu, Q. Identification of the immunodominant epitope region in phospholipase A2 receptor-mediating autoantibody binding in idiopathic membranous nephropathy. J. Am. Soc. Nephrol., 2015, 26(2), 291301.

[13] Kerjaschki, D. Pathogenetic concepts of membranous glomerulopathy (MGN). J. Nephrol., 2000, 13 (Suppl 3), S96-100.

[14] Polanco, N.; Gutierrez, E.; Covarsi, A.; Ariza, F.; Carreno, A.; Vigil, A.; Baltar, J.; FernandezFresnedo, G.; Martin, C.; Pons, S.; Lorenzo, D.; Bernis, C.; Arrizabalaga, P.; Fernandez-Juarez, G.; Barrio, V.; Sierra, M.; Castellanos, I.; Espinosa, M.; Rivera, F.; Oliet, A.; Fernandez-Vega, F.; Praga, M.; Grupo de Estudio de las Enfermedades Glomerulares de la Sociedad Espanola de, N. Spontaneous remission of nephrotic syndrome in idiopathic membranous nephropathy. J. Am. Soc. Nephrol., 2010, 21(4), 697-704.

[15] Polanco, N.; Gutierrez, E.; Rivera, F.; Castellanos, I.; Baltar, J.; Lorenzo, D.; Praga, M.; Grupo de Estudio de las Enfermedades Glomerulares de la Sociedad Espanola de, N. Spontaneous remission of nephrotic syndrome in membranous nephropathy with chronic renal impairment. Nephrol. Dial. Transplant., 2012, 27(1), 231-234.

[16] Glassock, R.J. Diagnosis and natural course of membranous nephropathy. Semin. Nephrol., 2003, 23(4), 324-332.

[17] Nangaku, M.; Shankland, S.J.; Couser, W.G. Cellular response to injury in membranous nephropathy. $J$. Am. Soc. Nephrol., 2005, 16(5), 1195-1204.

[18] Imai, H.; Hamai, K.; Komatsuda, A.; Ohtani, H.; Miura, A.B. IgG subclasses in patients with membranoproliferative glomerulonephritis, membranous nephropathy, and lupus nephritis. Kidney Int., 1997, 51(1), 270-276.

[19] Kuroki, A.; Shibata, T.; Honda, H.; Totsuka, D.; Kobayashi, K.; Sugisaki, T. Glomerular and serum IgG subclasses in diffuse proliferative lupus nephritis, membranous lupus nephritis, and idiopathic membranous nephropathy. Intern. Med., 2002, 41(11), 936-942. 
[20] Ohtani, H.; Wakui, H.; Komatsuda, A.; Okuyama, S.; Masai, R.; Maki, N.; Kigawa, A.; Sawada, K.; Imai, H. Distribution of glomerular IgG subclass deposits in malignancy-associated membranous nephropathy. Nephrol. Dial. Transplant., 2004, 19(3), 574-579.

[21] Segawa, Y.; Hisano, S.; Matsushita, M.; Fujita, T.; Hirose, S.; Takeshita, M.; Iwasaki, H. IgG subclasses and complement pathway in segmental and global membranous nephropathy. Pediatr. Nephrol., 2010, 25(6), 1091-1099.

[22] Glassock, R.J. Human idiopathic membranous nephropathy--a mystery solved? N. Engl. J. Med., 2009, 361(1), 81-83.

[23] Dixon, F.J.; Feldman, J.D.; Vazquez, J.J. Experimental glomerulonephritis. The pathogenesis of a laboratory model resembling the spectrum of human glomerulonephritis. J. Exp. Med., 1961, 113, 899-920.

[24] Wilson, C.B.; Dixon, F.J. Quantitation of acute and chronic serum sickness in the rabbit. J. Exp. Med., 1971, 134(3 Pt 2), 7s-8s.

[25] Heymann, W.; Hackel, D.B.; Harwood, S.; Wilson, S.G.; Hunter, J.L. Production of nephrotic syndrome in rats by Freund's adjuvants and rat kidney suspensions. Proc. Soc. Exp. Biol. Med., 1959, 100(4), 660-664.

[26] Border, W.A.; Ward, H.J.; Kamil, E.S.; Cohen, A.H. Induction of membranous nephropathy in rabbits by administration of an exogenous cationic antigen. $J$. Clin. Invest., 1982, 69(2), 451-461.

[27] Kerjaschki, D.; Farquhar, M.G. The pathogenic antigen of Heymann nephritis is a membrane glycoprotein of the renal proximal tubule brush border. Proc. Natl. Acad. Sci. U.S.A., 1982, 79(18), 5557-5561.

[28] Kerjaschki, D.; Farquhar, M.G. Immunocytochemical localization of the Heymann nephritis antigen (GP330) in glomerular epithelial cells of normal Lewis rats. J. Exp. Med., 1983, 157(2), 667-686.

[29] Cybulsky, A.V.; Quigg, R.J.; Salant, D.J. Experimental membranous nephropathy redux. Am. J. Physiol. Renal. Physiol., 2005, 289(4), F660-671.

[30] Cunningham, P.N.; Quigg, R.J. Contrasting roles of complement activation and its regulation in membranous nephropathy. J. Am. Soc. Nephrol., 2005, 16(5), 1214-1222.

[31] Neale, T.J.; Ojha, P.P.; Exner, M.; Poczewski, H.; Ruger, B.; Witztum, J.L.; Davis, P.; Kerjaschki, D. Proteinuria in passive Heymann nephritis is associated with lipid peroxidation and formation of adducts on type IV collagen. J. Clin. Invest., 1994, 94(4), 1577-1584.

[32] Ronco, P.; Debiec, H. Target antigens and nephritogenic antibodies in membranous nephropathy: of rats and men. Semin. Immunopathol., 2007, 29(4), 445-458.

[33] Debiec, H.; Guigonis, V.; Mougenot, B.; Decobert, F.; Haymann, J.P.; Bensman, A.; Deschenes, G.; Ronco, P.M. Antenatal membranous glomerulonephritis due to anti-neutral endopeptidase antibodies. N. Engl. J. Med., 2002, 346(26), 20532060 .

[34] Tomas, N.M.; Beck, L.H., Jr.; Meyer-Schwesinger, C.; Seitz-Polski, B.; Ma, H.; Zahner, G.; Dolla, G.; Hoxha, E.; Helmchen, U.; Dabert-Gay, A.S.; Debayle, D.; Merchant, M.; Klein, J.; Salant, D.J.; Stahl, R.A.; Lambeau, G. Thrombospondin type-1 domain-containing 7A in idiopathic membranous nephropathy. N. Engl. J. Med., 2014, 371(24), $2277-$ 2287.

[35] Hoxha, E.; Harendza, S.; Zahner, G.; Panzer, U.; Steinmetz, O.; Fechner, K.; Helmchen, U.; Stahl, R.A. An immunofluorescence test for phospholipaseA(2)-receptor antibodies and its clinical usefulness in patients with membranous glomerulonephritis. Nephrol. Dial. Transplant., 2011, 26(8), 2526-2532.

[36] Qin, W.; Beck, L.H., Jr.; Zeng, C.; Chen, Z.; Li, S.; Zuo, K.; Salant, D.J.; Liu, Z. Anti-phospholipase A2 receptor antibody in membranous nephropathy. $J$. Am. Soc. Nephrol., 2011, 22(6), 1137-1143.

[37] Oh, Y.J.; Yang, S.H.; Kim, D.K.; Kang, S.W.; Kim, Y.S. Autoantibodies against phospholipase A2 receptor in Korean patients with membranous nephropathy. PLoS One, 2013, 8(4), e62151.

[38] Akiyama, S.; Akiyama, M.; Imai, E.; Ozaki, T.; Matsuo, S.; Maruyama, S. Prevalence of antiphospholipase A2 receptor antibodies in Japanese patients with membranous nephropathy. Clin. Exp. Nephrol., 2014.

[39] Ardalan, M.; Ghafari, A.; Hamzavi, F.; Nasri, H.; Baradaran, B.; Majidi, J.; Nikbin, B. Antiphospholipase A2 receptor antibody in idiopathic membranous nephropathy: A report from Iranian population. J. Nephropathol., 2013, 2(4), 241-248.

[40] Hoxha, E.; Kneissler, U.; Stege, G.; Zahner, G.; Thiele, I.; Panzer, U.; Harendza, S.; Helmchen, U.M.; Stahl, R.A. Enhanced expression of the M-type phospholipase A2 receptor in glomeruli correlates with serum receptor antibodies in primary 
membranous nephropathy. Kidney Int., 2012, 82(7), 797-804.

[41] Hofstra, J.M.; Debiec, H.; Short, C.D.; Pelle, T.; Kleta, R.; Mathieson, P.W.; Ronco, P.; Brenchley, P.E.; Wetzels, J.F. Antiphospholipase A2 receptor antibody titer and subclass in idiopathic membranous nephropathy. J. Am. Soc. Nephrol., 2012, 23(10), 1735-1743.

[42] Svobodova, B.; Honsova, E.; Ronco, P.; Tesar, V.; Debiec, H. Kidney biopsy is a sensitive tool for retrospective diagnosis of PLA2R-related membranous nephropathy. Nephrol. Dial. Transplant., 2013, 28(7), 1839-1844.

[43] Larsen, C.P.; Messias, N.C.; Silva, F.G.; Messias, E.; Walker, P.D. Determination of primary versus secondary membranous glomerulopathy utilizing phospholipase A2 receptor staining in renal biopsies. Mod. Pathol., 2013, 26(5), 709-715.

[44] Barrett, C.M.; Troxell, M.L.; Larsen, C.P.; Houghton, D.C. Membranous glomerulonephritis with crescents. Int. Urol. Nephrol., 2014, 46(5), 963-971.

[45] Debiec, H.; Martin, L.; Jouanneau, C.; Dautin, G.; Mesnard, L.; Rondeau, E.; Mousson, C.; Ronco, P. Autoantibodies specific for the phospholipase A2 receptor in recurrent and De Novo membranous nephropathy. Am. J. Transplant., 2011, 11(10), 21442152.

[46] Stahl, R.; Hoxha, E.; Fechner, K. PLA2R autoantibodies and recurrent membranous nephropathy after transplantation. N. Engl. J. Med., 2010, 363(5), 496-498.

[47] Quintana, L.F.; Blasco, M.; Seras, M.; Perez, N.S.; Lopez-Hoyos, M.; Villarroel, P.; Rodrigo, E.; Vinas, O.; Ercilla, G.; Diekmann, F.; Gomez-Roman, J.J.; Fernandez-Fresnedo, G.; Oppenheimer, F.; Arias, M.; Campistol, J.M. Antiphospholipase A2 receptor antibody levels predict the risk of posttransplantation recurrence of membranous nephropathy. Transplantation, 2015.

[48] Larsen, C.P.; Walker, P.D. Phospholipase A2 receptor (PLA2R) staining is useful in the determination of de novo versus recurrent membranous glomerulopathy. Transplantation, 2013, 95(10), 1259-1262.

[49] Zahner, G.; Meyer-Schwesinger, C.; Tomas, N.M.; Hoxha, E.; Wiech, T.; Stahl, R.A. In Development, and Morphologic Characteriziation of a Mouse Model of Membranous Nephropathy Involving the Human Phospholipase A2 Receptor, Kidney Week 2014, Philadelphia, PA, Nov. 11-16, 2014; American
Society of Nephrology: Florida, U.S.A., 2014; pp. 66A.

[50] Baker, P.J.; Ochi, R.F.; Schulze, M.; Johnson, R.J.; Campbell, C.; Couser, W.G. Depletion of C6 prevents development of proteinuria in experimental membranous nephropathy in rats. Am. J. Pathol., 1989, $135(1), 185-194$.

[51] Ma, H.; Sandor, D.G.; Beck, L.H., Jr. The role of complement in membranous nephropathy. Semin. Nephrol., 2013, 33(6), 531-542.

[52] Lhotta, K.; Wurzner, R.; Konig, P. Glomerular deposition of mannose-binding lectin in human glomerulonephritis. Nephrol. Dial. Transplant., 1999, 14(4), 881-886.

[53] Debiec, H.; Hanoy, M.; Francois, A.; Guerrot, D.; Ferlicot, S.; Johanet, C.; Aucouturier, P.; Godin, M.; Ronco, P. Recurrent membranous nephropathy in an allograft caused by IgG3kappa targeting the PLA2 receptor. J. Am. Soc. Nephrol., 2012, 23(12), 19491954.

[54] Okazaki, K.; Uchida, K.; Sumimoto, K.; Mitsuyama, T.; Ikeura, T.; Takaoka, M. Autoimmune pancreatitis: pathogenesis, latest developments and clinical guidance. Ther. Adv. Chronic Dis., 2014, 5(3), 104111.

[55] Hirayama, K.; Ebihara, I.; Yamamoto, S.; Kai, H.; Muro, K.; Yamagata, K.; Kobayashi, M.; Koyama, A. Predominance of type-2 immune response in idiopathic membranous nephropathy. Cytoplasmic cytokine analysis. Nephron, 2002, 91(2), 255-261.

[56] Kuroki, A.; Iyoda, M.; Shibata, T.; Sugisaki, T. Th2 cytokines increase and stimulate $\mathrm{B}$ cells to produce IgG4 in idiopathic membranous nephropathy. Kidney Int., 2005, 68(1), 302-310.

[57] Ancian, P.; Lambeau, G.; Mattei, M.G.; Lazdunski, M. The human $180-\mathrm{kDa}$ receptor for secretory phospholipases A2. Molecular cloning, identification of a secreted soluble form, expression, and chromosomal localization. J. Biol. Chem., 1995, 270(15), 8963-8970.

[58] Ishizaki, J.; Hanasaki, K.; Higashino, K.; Kishino, J.; Kikuchi, N.; Ohara, O.; Arita, H. Molecular cloning of pancreatic group I phospholipase A2 receptor. $J$. Biol. Chem., 1994, 269(8), 5897-5904.

[59] Llorca, O. Extended and bent conformations of the mannose receptor family. Cell Mol. Life Sci., 2008, 65(9), 1302-1310.

[60] East, L.; Isacke, C.M. The mannose receptor family. Biochem. Biophys. Acta., 2002, 1572(2-3), 364-386. 
[61] Liu, Y.; Chirino, A.J.; Misulovin, Z.; Leteux, C.; Feizi, T.; Nussenzweig, M.C.; Bjorkman, P.J. Crystal structure of the cysteine-rich domain of mannose receptor complexed with a sulfated carbohydrate ligand. J. Exp. Med., 2000, 191(7), 1105-1116.

[62] Sticht, H.; Pickford, A.R.; Potts, J.R.; Campbell, I.D. Solution structure of the glycosylated second type 2 module of fibronectin. J. Mol. Biol., 1998, 276(1), 177-187.

[63] Weis, W.I.; Kahn, R.; Fourme, R.; Drickamer, K.; Hendrickson, W.A. Structure of the calciumdependent lectin domain from a rat mannose-binding protein determined by MAD phasing. Science, 1991, 254(5038), 1608-1615.

[64] Boskovic, J.; Arnold, J.N.; Stilion, R.; Gordon, S.; Sim, R.B.; Rivera-Calzada, A.; Wienke, D.; Isacke, C.M.; Martinez-Pomares, L.; Llorca, O. Structural model for the mannose receptor family uncovered by electron microscopy of Endo180 and the mannose receptor. J. Biol. Chem., 2006, 281(13), 8780-8787.

[65] Hanasaki, K.; Arita, H. Purification and characterization of a high-affinity binding protein for pancreatic-type phospholipase A2. Biochem. Biophys. Acta., 1992, 1127(3), 233-241.

[66] Zvaritch, E.; Lambeau, G.; Lazdunski, M. Endocytic properties of the M-type $180-\mathrm{kDa}$ receptor for secretory phospholipases A2. J Biol Chem, 1996, 271(1), 250-257.

[67] Hanasaki, K.; Arita, H. Phospholipase A2 receptor: a regulator of biological functions of secretory phospholipase A2. Prostag. Oth. Lipid M., 2002, 6869, 71-82.

[68] Murakami, M.; Taketomi, Y.; Girard, C.; Yamamoto, K.; Lambeau, G. Emerging roles of secreted phospholipase A2 enzymes: Lessons from transgenic and knockout mice. Biochimie., 2010, 92(6), 561-582.

[69] Augert, A.; Payre, C.; de Launoit, Y.; Gil, J.; Lambeau, G.; Bernard, D. The M-type receptor PLA2R regulates senescence through the p53 pathway. EMBO Rep., 2009, 10(3), 271-277.

[70] Vindrieux, D.; Augert, A.; Girard, C.A.; Gitenay, D.; Lallet-Daher, H.; Wiel, C.; Le Calve, B.; Gras, B.; Ferrand, M.; Verbeke, S.; de Launoit, Y.; Leroy, X.; Puisieux, A.; Aubert, S.; Perrais, M.; Gelb, M.; Simonnet, H.; Lambeau, G.; Bernard, D. PLA2R1 mediates tumor suppression by activating JAK2. Cancer Res., 2013, 73(20), 6334-6345.

[71] Granata, F.; Staiano, R.I.; Loffredo, S.; Petraroli, A.; Genovese, A.; Marone, G.; Triggiani, M. The role of mast cell-derived secreted phospholipases A2 in respiratory allergy. Biochimie., 2010, 92(6), 588-593.

[72] Hanasaki, K.; Ono, T.; Saiga, A.; Morioka, Y.; Ikeda, M.; Kawamoto, K.; Higashino, K.; Nakano, K.; Yamada, K.; Ishizaki, J.; Arita, H. Purified group X secretory phospholipase $\mathrm{A}(2)$ induced prominent release of arachidonic acid from human myeloid leukemia cells. J. Biol. Chem., 1999, 274(48), 3420334211 .

[73] Hanasaki, K.; Yokota, Y.; Ishizaki, J.; Itoh, T.; Arita, $\mathrm{H}$. Resistance to endotoxic shock in phospholipase A2 receptor-deficient mice. J. Biol. Chem., 1997, 272(52), 32792-32797.

[74] Higashino, K.; Ishizaki, J.; Kishino, J.; Ohara, O.; Arita, H. Structural comparison of phospholipase-A2binding regions in phospholipase-A2 receptors from various mammals. Eur. J. Biochem., 1994, 225(1), 375-382.

[75] Silliman, C.C.; Moore, E.E.; Zallen, G.; Gonzalez, R.; Johnson, J.L.; Elzi, D.J.; Meng, X.; Hanasaki, K.; Ishizaki, J.; Arita, H.; Ao, L.; England, K.M.; Banerjee, A. Presence of the M-type sPLA(2) receptor on neutrophils and its role in elastase release and adhesion. Am. J. Physiol. Cell. Physiol., 2002, 283(4), C1102-1113.

[76] Moses, E.K.; Freed, K.A.; Brennecke, S.P.; Rice, G.E. Distribution of the phospholipase A2 receptor messenger RNA in human gestational tissues. Placenta, 1998, 19(1), 35-40.

[77] Menschikowski, M.; Platzbecker, U.; Hagelgans, A.; Vogel, M.; Thiede, C.; Schonefeldt, C.; Lehnert, R.; Eisenhofer, G.; Siegert, G. Aberrant methylation of the M-type phospholipase $A(2)$ receptor gene in leukemic cells. BMC Cancer, 2012, 12, 576.

[78] Stanescu, H.C.; Arcos-Burgos, M.; Medlar, A.; Bockenhauer, D.; Kottgen, A.; Dragomirescu, L.; Voinescu, C.; Patel, N.; Pearce, K.; Hubank, M.; Stephens, H.A.; Laundy, V.; Padmanabhan, S.; Zawadzka, A.; Hofstra, J.M.; Coenen, M.J.; den Heijer, M.; Kiemeney, L.A.; Bacq-Daian, D.; Stengel, B.; Powis, S.H.; Brenchley, P.; Feehally, J.; Rees, A.J.; Debiec, H.; Wetzels, J.F.; Ronco, P.; Mathieson, P.W.; Kleta, R. Risk HLA-DQA1 and PLA(2)R1 alleles in idiopathic membranous nephropathy. $N$. Engl. J. Med., 2011, 364(7), 616-626.

[79] Coenen, M.J.; Hofstra, J.M.; Debiec, H.; Stanescu, H.C.; Medlar, A.J.; Stengel, B.; Boland-Auge, A.; Groothuismink, J.M.; Bockenhauer, D.; Powis, S.H.; Mathieson, P.W.; Brenchley, P.E.; Kleta, R.; Wetzels, J.F.; Ronco, P. Phospholipase A2 receptor (PLA2R1) 
sequence variants in idiopathic membranous nephropathy. J. Am. Soc. Nephrol., 2013, 24(4), 677683.

[80] Behnert, A.; Fritzler, M.J.; Teng, B.; Zhang, M.; Bollig, F.; Haller, H.; Skoberne, A.; Mahler, M.; Schiffer, M. An anti-phospholipase A2 receptor quantitative immunoassay and epitope analysis in membranous nephropathy reveals different antigenic domains of the receptor. PLoS One, 2013, 8(4), e61669.

[81] Rivera-Calzada, A.; Robertson, D.; MacFadyen, J.R.; Boskovic, J.; Isacke, C.M.; Llorca, O. Threedimensional interplay among the ligand-binding domains of the urokinase-plasminogen-activatorreceptor-associated protein, Endo180. EMBO Rep., 2003, 4(8), 807-812.

[82] Fresquet, M.; Jowitt, T.A.; Gummadova, J.; Collins, R.; O'Cualain, R.; McKenzie, E.A.; Lennon, R.; Brenchley, P.E. Identification of a major epitope recognized by PLA2R autoantibodies in primary membranous nephropathy. J. Am. Soc. Nephrol., 2015, 26(2), 302-313.

[83] Fresquet, M.; Jowitt, T.A.; Gummadova, J.O.; McKenzie, E.A.; Lennon, R.; Brenchley, P.E. In Understanding the Structure of PLA2R: Insights into Formation of the Immunodominant Epitope Recognized by Autoantibodies in Patients with Idiopathic Membranous Nephropathy, ASN Kidney Week 2013, Atlanta, GA, Nov. 5-10, 2013; American Society of Nephrology: Florida, U.S.A., 2013; pp. $21 \mathrm{~A}$.

[84] Salant, D.J. Genetic variants in membranous nephropathy: perhaps a perfect storm rather than a straightforward conformeropathy? J. Am. Soc. Nephrol., 2013, 24(4), 525-528.

[85] Zhu, Q.; Kao, L. In $P L A_{2} R$ tightly associates with integrin $a_{3} b_{1}$ in the podocyte membrane: A new insight into IMN pathogenesis, Kidney Week 2013, Atlanta, GA, Nov. 5-10, 2013; American Society of Nephrology: Florida, U.S.A., 2013; pp. 567A.

[86] Luo, B.H.; Carman, C.V.; Springer, T.A. Structural basis of integrin regulation and signaling. Annu. Rev. Immunol., 2007, 25, 619-647.
[87] Dahnrich, C.; Komorowski, L.; Probst, C.; SeitzPolski, B.; Esnault, V.; Wetzels, J.F.; Hofstra, J.M.; Hoxha, E.; Stahl, R.A.; Lambeau, G.; Stocker, W.; Schlumberger, W. Development of a standardized ELISA for the determination of autoantibodies against human M-type phospholipase A2 receptor in primary membranous nephropathy. Clinica Chimica Acta, 2013, 421, 213-218.

[88] Timmermans, S.A.; Damoiseaux, J.G.; HeeringsRewinkel, P.T.; Ayalon, R.; Beck, L.H., Jr.; Schlumberger, W.; Salant, D.J.; van Paassen, P.; Tervaert, J.W.; Limburg Renal, R. Evaluation of antiPLA2R1 as measured by a novel ELISA in patients with idiopathic membranous nephropathy: a cohort study. Am. J. Clin. Pathol., 2014, 142(1), 29-34.

[89] Behnert, A.; Schiffer, M.; Muller-Deile, J.; Beck, L.H., Jr.; Mahler, M.; Fritzler, M.J. Antiphospholipase $\mathrm{A}(2)$ receptor autoantibodies: a comparison of three different immunoassays for the diagnosis of idiopathic membranous nephropathy. $J$. Immunol. Res., 2014, 2014, 143274.

[90] Beck, L.H., Jr.; Fervenza, F.C.; Beck, D.M.; Bonegio, R.G.; Malik, F.A.; Erickson, S.B.; Cosio, F.G.; Cattran, D.C.; Salant, D.J. Rituximab-induced depletion of anti-PLA2R autoantibodies predicts response in membranous nephropathy. J. Am. Soc. Nephrol., 2011, 22(8), 1543-1550.

[91] Ruggenenti, P.; Debiec, H.; Ruggiero, B.; Chianca, A.; Pelle, T.; Gaspari, F.; Suardi, F.; Gagliardini, E.; Orisio, S.; Benigni, A.; Ronco, P.; Remuzzi, G. AntiPhospholipase A2 Receptor Antibody Titer Predicts Post-Rituximab Outcome of Membranous Nephropathy. J. Am. Soc. Nephrol., 2015.

[92] Meyrier, A.; Ronco, P. Allotransplantation using a diseased kidney: when a swallow makes a summer. Nephrol Dial Transplant, 2014, 29(12), 2164-2166.

[93] Harrison, L.C. The prospect of vaccination to prevent type 1 diabetes. Hum. Vaccin., 2005, 1(4), 143-150.

[94] Harrison, L.C.; Wentworth, J.M.; Zhang, Y.; Bandala-Sanchez, E.; Bohmer, R.M.; Neale, A.M.; Stone, N.L.; Naselli, G.; Bosco, J.J.; Auyeung, P.; Rashidi, M.; Augstein, P.; Morahan, G. Antigenbased vaccination and prevention of type 1 diabetes. Curr. Diab. Rep., 2013, 13(5), 616-623. 